\title{
The Seasonal Variation Characteristics and Influencing Factors of Soil Ecological Stoichiometry with Different Land Use Types in Karst Rocky Desertification Area in Southwest China
}

\author{
Yongkuan Chi \\ Guizhou Normal University \\ Shuzhen Song \\ Guizhou Normal University \\ Kangning Xiong ( $\nabla$ xiongkangning@sina.com ) \\ Guizhou Normal University
}

\section{Research Article}

Keywords: Karst, Land use types, Ecological stoichiometry, Seasonal variations, Environmental factors

Posted Date: October 15th, 2021

DOI: https://doi.org/10.21203/rs.3.rs-941399/v1

License: (c) (i) This work is licensed under a Creative Commons Attribution 4.0 International License. Read Full License 


\section{Abstract}

Aims Study the influence of different land use types on the stoichiometric characteristics of soil C, N, P, and explore its response to environmental factors.

Methods The research takes soils of 6 different land use types (shrub grassland, dry land, economic fruit forest, sparse forest, primary forest, and waste grassland) from the demonstration area for comprehensive control of karst rocky desertification in southwest ChinaGrand Canyon of Guanling Huajiang, Guizhou as the research object.

Results The result shows that the $\mathrm{C}, \mathrm{N}$, and $\mathrm{P}$ contents of primary forest among the six different land use types are the highest, which are significantly higher than that of shrub grassland, dry land, economic fruit forest, and waste grassland. The $\mathrm{C}$ and $\mathrm{N}$ contents of waste grassland are the lowest, which are significantly lower than that of primary forest, sparse forest and shrub grassland, roughly represented as primary forest>sparse forest>shrub grassland >dry land>economic fruit forest>waste grassland. The $\mathrm{C}, \mathrm{N}$, and $\mathrm{P}$ contents show certain seasonal variations, which are higher in autumn than in spring. In addition, soil C, N, and P contents show a trend of decreasing with the increase of soil layer thickness, with obvious surface accumulation characteristics.

Conclusions The soil C:N of spring and autumn in 6 different land use types are lower than the national and global averages, and the C:P and N:P are much higher than the average value of karst soils in the same area, indicating that the soil in the study area is relatively sufficient in $\mathrm{N}$ but $\mathrm{P}$ is relatively lacking. Redundancy analysis shows that soil $\mathrm{C}, \mathrm{N}$ and $\mathrm{P}$ in different land use types are affected. The main environmental factors for the change of stoichiometric characteristics are the human activity intensity, landform, and the slope. The research results will provide relevant theoretical support for the control of rocky desertification and vegetation restoration in southwest karst.

\section{Introduction}

Karst landforms are various surface and underground landscapes and phenomena formed by various external forces such as soluble rocks' dissolution and precipitation, erosion and deposition (Jiang et al. 2014; Sheng et al. 2015). The total area of global karst landforms has reached $5.1 \times 10^{7} \mathrm{~km}^{2}$, occupying $10 \%$ of the total area of the earth (Wang et al. 2019). The karst area in southwest China regarding Guizhou as the center has an area of more than $5.5 \times 10^{5} \mathrm{~km}^{2}$. It is not only the three largest karst concentrated distribution areas in the world with the most complete geomorphological types, but also one of the four fragile ecological areas in China (Zhang et al. 2018). The fragile ecological environment and the unreasonable socio-economic activities of human beings can easily cause vegetation destruction, soil erosion, decline or even loss of land productivity, the gradual exposure of rocks, and the evolution process or result of rocky desertification landscapes on the surface (Xiong et al. 2015; Chi et al. 2020). At present, there are more than 100 million people living in this area, with a large and concentrated population density. At the same time, this area is also one of the main areas of poverty population living in China. As a prominent contradiction between people and land is, the fragile natural environment and unreasonable human activities have exacerbated karst rocky desertification, which has become an important ecological problem that restricts the sustainable development of society and economy in the southwest karst (Wang et al. 2002; Zeng et al. 2018). For this reason, since the 1990s, China has successively initiated a number of major ecosystem projects of rocky desertification restoration and management, including major engineering measures such as closing mountains for afforestation and returning farmland to forests, and achieved certain results. However, the rocky desertification area after treatment still has a series of problems such as simple ecosystem structure, poor stability, and weak resistance (Xiong et al. 2012).

Soil is an important material component of the terrestrial ecosystem and the carrier of many ecological processes (Cai et al. 2020). Elements such as $\mathrm{C}, \mathrm{N}, \mathrm{P}$, and $\mathrm{K}$ in the soil are often essential elements for plant growth, which have an important impact on plant individual growth, population dynamics, community stability and succession (Wardle et al. 2004; Liu et al. 2005). Due to the dual interference of human activities and natural cycles, the nutrient elements in the soil can produce irregular dynamic changes, which affect the growth and development of plants and the material and energy cycle of terrestrial ecosystems (Gao et al. 2019). Due to the rugged and uneven surface of the karst area, the soil also has spatial discontinuity and complexity, so diversified land use types have been formed in the karst mountainous area (Wu et al. 2020). At present, although there have been a large number of reports on the ecological stoichiometry of C, N and P in karst soils (Zeng et al. 2015; Wu et al. 2019; Sun et al. 2021; Zhao et al. 2021), most of them focus on the characteristics of soil nutrient content and its spatial variation in the process of rocky desertification succession (Wang et al. 2018). However, there are relatively few studies on the seasonal dynamics of soil nutrient stoichiometric characteristics and its environmental influencing factors, which severely restricts the in-depth study of soil stoichiometric characteristics in karst ecosystems.

Page $2 / 13$ 
Thus, this study takes the soil from karst rocky desertification area in southwest China as the object to study the seasonal variation characteristics of soil C, N, and P under 6 different land use types: shrub grassland, waste grassland, dry land, economic fruit forest, sparse forest, and primary forest. Then, discuss the impact of environmental factors (rocky desertification grade, landform, altitude, slope, aspect, rock exposure rate, human activity intensity) on it, in order to provide scientific basis for the control of rocky desertification and vegetation restoration in southwestern karst rocky desertification areas.

\section{Materials And Methods Experimental site}

The study area is located on both banks of the gorge of the Huajiang section of the Beipanjiang River at the junction of Guanling County and Zhenfeng County, Guizhou Province ( $\left.25^{\circ} 38^{\prime} 19^{\prime \prime}-25^{\circ} 41^{\prime} 32^{\prime \prime} \mathrm{N}, 105^{\circ} 38^{\prime} 31^{\prime \prime}-106^{\circ} 40^{\prime} 51^{\prime \prime E}\right)$. As a typical karst plateau canyon landform, it is widely distributed carbonate rocks, with a $45-1450 \mathrm{~m}$ undulating terrain, relatively heightened $1000 \mathrm{~m}$. This area belongs to the subtropical dry-hot valley climate, with an average annual temperature of $18.4{ }^{\circ} \mathrm{C}$, and the average rainfall is $1100 \mathrm{~mm}$ and mostly concentrated from May to September. The vegetation is subtropical evergreen and deciduous mixed broadleaf-conifer forest, growing mainly in yellow soil and yellow lime soil. Due to the fragile ecological environment and unreasonable human activities, the vegetation in this area is seriously damaged with a serious rocky desertification, and now it is mainly secondary vegetation. The wild vegetation includes Pinus massoniana, Ligustrum lucidum, Platycladus orientalis, etc., and the shrubs include Pyracantha fortuneana, Broussonetia papyrifera, etc., while artificial forest includes Zanthoxylum bungeanum, Hylocereus undulatus, Lonicera Japonica, etc.

\section{Experimental design}

Carrying out field surveys and combining Landsat's remote sensing image maps, selecting 6 representative land use types in the demonstration area: shrub grassland, dry land, economic fruit forest, sparse forest, primary forest, and waste grassland for sample setting (Table 1). Set three $20 \times 20 \mathrm{~m}$ squares in each land use type, and select 5 sampling points in each square according to the Sshaped layout method. In April and August 2020, each sampling point should be $0 \varangle 5 \mathrm{~cm}, 5 \nabla 10 \mathrm{~cm}, 10 \varangle 20 \mathrm{~cm}$ collected in 3 layers. During the sampling process, the litter on the surface of the soil layer was first removed. Each sample would mix the soil of the same layer evenly to form a mixed soil sample number and bag it back to the laboratory. After natural drying, use a ball mill to grind the soil and pass it through a 100-mesh sieve for related chemical analysis. According to the analysis method of Soil Agrochemical Analysis (Lu 1999), the total $\mathrm{C}$ of the soil was determined by the potassium dichromate oxidation-external heating method, the total $\mathrm{N}$ was determined by the Kjeldahl method, and the total $\mathrm{P}$ was determined by the elimination molybdenum-antimony anticolorimetric method. 
Table 1

Basic information of the sampling sites

\begin{tabular}{|c|c|c|c|c|c|c|c|c|c|}
\hline $\begin{array}{l}\text { Site } \\
\text { number }\end{array}$ & $\begin{array}{l}\text { Land use } \\
\text { types }\end{array}$ & $\begin{array}{l}\text { Latitude and } \\
\text { longitude of } \\
\text { central point }\end{array}$ & Altitude(m) & $\begin{array}{l}\text { Slope } \\
(0)\end{array}$ & aspect & $\begin{array}{l}\text { Human } \\
\text { activity } \\
\text { intensity }\end{array}$ & Landforms & $\begin{array}{l}\text { Rock } \\
\text { exposure } \\
\text { rate(\%) }\end{array}$ & $\begin{array}{l}\text { Rocky } \\
\text { desertification } \\
\text { grades }\end{array}$ \\
\hline 1 & $\begin{array}{l}\text { shrub } \\
\text { grassland }\end{array}$ & $\begin{array}{l}105^{\circ} 38^{\prime} 38 \\
" E, 25^{\circ} 41^{\prime} 8 \\
" N\end{array}$ & 738 & 34 & southwest & moderate & $\begin{array}{l}\text { eroded } \\
\text { steep } \\
\text { slope }\end{array}$ & 63 & high degree \\
\hline 2 & $\begin{array}{l}\text { shrub } \\
\text { grassland }\end{array}$ & $\begin{array}{l}105^{\circ} 39^{\prime} 5^{\prime \prime} \mathrm{E}, \\
25^{\circ} 39^{\prime} 33^{\prime \prime} \mathrm{N}\end{array}$ & 718 & 23 & southwest & moderate & $\begin{array}{l}\text { peak } \\
\text { cluster } \\
\text { platform }\end{array}$ & 50 & high degree \\
\hline 3 & $\begin{array}{l}\text { shrub } \\
\text { grassland }\end{array}$ & $\begin{array}{l}105^{\circ} 38^{\prime} 55^{\prime \prime} \mathrm{E} \\
25^{\circ} 39^{\prime} 51^{\prime \prime N}\end{array}$ & 852 & 26 & southwest & weak & $\begin{array}{l}\text { peak } \\
\text { cluster } \\
\text { platform }\end{array}$ & 47 & middle degree \\
\hline 4 & dry land & $\begin{array}{l}105^{\circ} 38^{\prime} 39^{\prime \prime} \mathrm{E} \\
25^{\circ} 39^{\prime} 19^{\prime \prime} \mathrm{N}\end{array}$ & 721 & 9 & southeast & $\begin{array}{l}\text { extremely } \\
\text { strong }\end{array}$ & valley & 5 & nil \\
\hline 5 & dry land & $\begin{array}{l}105^{\circ} 37^{\prime} 28^{\prime \prime} \mathrm{E} \\
25^{\circ} 41^{\prime} 50^{\prime \prime} \mathrm{N}\end{array}$ & 981 & 13 & southwest & $\begin{array}{l}\text { extremely } \\
\text { strong }\end{array}$ & $\begin{array}{l}\text { eroded } \\
\text { gully }\end{array}$ & 13 & low degree \\
\hline 6 & dry land & $\begin{array}{l}105^{\circ} 37^{\prime} 24^{\prime \prime} \mathrm{E} \\
25^{\circ} 41^{\prime} 51^{\prime \prime N}\end{array}$ & 952 & 17 & southeast & strong & $\begin{array}{l}\text { eroded } \\
\text { gully }\end{array}$ & 16 & low degree \\
\hline 7 & $\begin{array}{l}\text { economic } \\
\text { fruit } \\
\text { forest }\end{array}$ & $\begin{array}{l}105^{\circ} 38^{\prime} 45^{\prime \prime} \mathrm{E} \\
25^{\circ} 41^{\prime} 7 " \mathrm{~N}\end{array}$ & 720 & 27 & southwest & strong & $\begin{array}{l}\text { eroded } \\
\text { gully }\end{array}$ & 19 & low degree \\
\hline 8 & $\begin{array}{l}\text { economic } \\
\text { fruit } \\
\text { forest }\end{array}$ & $\begin{array}{l}105^{\circ} 40^{\prime} 8^{\prime \prime} \mathrm{E}, \\
25^{\circ} 39^{\prime} 59^{\prime \prime} \mathrm{N}\end{array}$ & 657 & 19 & northwest & strong & valley & 23 & low degree \\
\hline 9 & $\begin{array}{l}\text { economic } \\
\text { fruit } \\
\text { forest }\end{array}$ & $\begin{array}{l}105^{\circ} 38^{\prime} 53^{\prime \prime} \mathrm{E} \\
25^{\circ} 39^{\prime} 50^{\prime \prime} \mathrm{N}\end{array}$ & 700 & 24 & northwest & moderate & valley & 47 & middle degree \\
\hline 10 & $\begin{array}{l}\text { sparse } \\
\text { forest }\end{array}$ & $\begin{array}{l}105^{\circ} 37^{\prime} 9^{\prime \prime} \mathrm{E}, \\
25^{\circ} 42^{\prime} 17^{\prime \prime} \mathrm{N}\end{array}$ & 1194 & 19 & northeast & moderate & $\begin{array}{l}\text { peak } \\
\text { cluster } \\
\text { platform }\end{array}$ & 69 & high degree \\
\hline 11 & $\begin{array}{l}\text { sparse } \\
\text { forest }\end{array}$ & $\begin{array}{l}105^{\circ} 37^{\prime} 46^{\prime \prime} \mathrm{E} \\
25^{\circ} 42^{\prime} 29^{\prime \prime} \mathrm{N}\end{array}$ & 1082 & 29 & northeast & weak & $\begin{array}{l}\text { peak } \\
\text { cluster } \\
\text { platform }\end{array}$ & 78 & $\begin{array}{l}\text { extremely } \\
\text { high degree }\end{array}$ \\
\hline 12 & $\begin{array}{l}\text { sparse } \\
\text { forest }\end{array}$ & $\begin{array}{l}105^{\circ} 38^{\prime} 37^{\prime \prime} \mathrm{E} \\
25^{\circ} 41^{\prime} 7 " \mathrm{~N}\end{array}$ & 911 & 25 & southwest & moderate & $\begin{array}{l}\text { eroded } \\
\text { steep } \\
\text { slope }\end{array}$ & 44 & middle degree \\
\hline 13 & $\begin{array}{l}\text { primary } \\
\text { forest }\end{array}$ & $\begin{array}{l}105^{\circ} 38^{\prime} 38^{\prime \prime} \mathrm{E} \\
25^{\circ} 39^{\prime} 23^{\prime \prime} \mathrm{N}\end{array}$ & 817 & 25 & southeast & none & $\begin{array}{l}\text { eroded } \\
\text { platform }\end{array}$ & 4 & low degree \\
\hline 14 & $\begin{array}{l}\text { primary } \\
\text { forest }\end{array}$ & $\begin{array}{l}105^{\circ} 38^{\prime} 35^{\prime \prime} \mathrm{E} \\
25^{\circ} 39^{\prime} 28^{\prime \prime} \mathrm{N}\end{array}$ & 820 & 28 & northwest & none & $\begin{array}{l}\text { peak } \\
\text { cluster } \\
\text { platform }\end{array}$ & 10 & nil \\
\hline 15 & $\begin{array}{l}\text { primary } \\
\text { forest }\end{array}$ & $\begin{array}{l}105^{\circ} 38^{\prime} 24^{\prime \prime} \mathrm{E} \\
25^{\circ} 39^{\prime} 19^{\prime \prime} \mathrm{N}\end{array}$ & 1080 & 17 & northwest & weak & $\begin{array}{l}\text { eroded } \\
\text { platform }\end{array}$ & 3 & nil \\
\hline 16 & $\begin{array}{l}\text { waste } \\
\text { grassland }\end{array}$ & $\begin{array}{l}105^{\circ} 36^{\prime} 45^{\prime \prime} \mathrm{E} \\
25^{\circ} 42^{\prime} 28^{\prime \prime} \mathrm{N}\end{array}$ & 879 & 44 & southeast & weak & $\begin{array}{l}\text { peak } \\
\text { cluster } \\
\text { platform }\end{array}$ & 13 & low degree \\
\hline 17 & $\begin{array}{l}\text { waste } \\
\text { grassland }\end{array}$ & $\begin{array}{l}105^{\circ} 37^{\prime} 28^{\prime \prime} \mathrm{E} \\
25^{\circ} 41^{\prime} 51^{\prime \prime N}\end{array}$ & 985 & 36 & southwest & moderate & $\begin{array}{l}\text { eroded } \\
\text { steep } \\
\text { slope }\end{array}$ & 36 & middle degree \\
\hline 18 & $\begin{array}{l}\text { waste } \\
\text { grassland }\end{array}$ & $\begin{array}{l}105^{\circ} 37^{\prime} 26 " \mathrm{E} \\
25^{\circ} 41^{\prime} 54^{\prime \prime} \mathrm{N}\end{array}$ & 923 & 29 & southwest & moderate & $\begin{array}{l}\text { eroded } \\
\text { steep } \\
\text { slope }\end{array}$ & 42 & middle degree \\
\hline
\end{tabular}




\section{Investigation and analysis of environmental factors}

In the sampling process at the field, GPS was used to accurately locate each plot, and obtain the environmental information of the longitude, latitude, altitude, and aspect of each plot. Referring to the standard of Xiong Kangning et al. (2015), karst rocky desertification was divided into five grades: nil rocky desertification, potential rocky desertification, low degree rocky desertification, middle degree rocky desertification, and high degree rocky desertification according to the rock exposure rate. Then, on the basis of the increasing rocky desertification grade, the value was assigned as 1-5. Referring to Sheng Maoyin et al. (2015), the grade of human activity interference was also divided into no, weak, moderate, strong, and extremely strong, and the value was assigned in the order of increasing interference grade as $1-5$. The landforms were divided into five grades: valley, eroded gully, eroded steep slope, peak cluster platform, and eroded platform, with values of $1-5$ in turn.

\section{Data processing}

Use Excel 2010 and SPSS 20.0 to perform statistical analysis on the data. Use one-way ANOVA to analyze the impact of different land use types on soil total C, total N, and total P indicators, and adopt LSD multiple comparison method for significance analysis, drawing by Origin 2018. Pearson correlation analysis was used to study the relationship between soil C, N, P and their ratios of different land use types and environmental factors, while the Canoco 5.0 software was used for further redundancy analysis (RDA) on the relationship between soil organic carbon, total nitrogen, total phosphorus and environmental factors. The data in the graph was the mean \pm standard error.

\section{Results And Analysis}

\section{Seasonal variation characteristics of soil C, N, and P contents in different land use types}

Figure 1 shows that the soil C, N, and P contents of 6 different land use types in the study area show certain seasonal variations, and the $\mathrm{C}, \mathrm{N}$, and $\mathrm{P}$ contents in autumn are higher than those in spring. The variation range of $\mathrm{C}, \mathrm{N}$ and $\mathrm{P}$ content in shrub grassland, dry land, economic fruit forest, sparse forest land, primary forest and waste grassland in spring are $18.49 \varangle 47.42 \mathrm{~g} \cdot \mathrm{kg}^{-1}, 1.61 \rrbracket 4.06 \mathrm{~g} \cdot \mathrm{kg}^{-1}$, $0.52 \varangle 1.13 \mathrm{~g} \cdot \mathrm{kg}^{-1}$, respectively. Among them, in the $0 \rrbracket 5 \mathrm{~cm}$ soil layer, the $\mathrm{C}, \mathrm{N}$, and $\mathrm{P}$ contents of the primary forest are the highest, which are significantly higher than that of the other five land use types. The $\mathrm{C}, \mathrm{N}$, and $\mathrm{P}$ contents of the waste grassland are the lowest, which are roughly expressed as primary forest $>$ sparse forest $>$ shrub grassland > dry land > economic fruit forest > waste grassland. The soil layer of $5 \square 10 \mathrm{~cm}$ and $10 \otimes 20 \mathrm{~cm}$ also show a similar pattern. The variation range of $\mathrm{C}, \mathrm{N}$ and $\mathrm{P}$ contents in shrub grassland, dry land, economic fruit forest, sparse forest, primary forest and waste grassland in autumn are $19.71 \llbracket 48.68 \mathrm{~g} \cdot \mathrm{kg}^{-1}, 1.74 \llbracket 4.53 \mathrm{~g} \cdot \mathrm{kg}^{-1}$, $0.66 \varangle 1.32 \mathrm{~g} \cdot \mathrm{kg}^{-1}$, respectively. In the soil layers of $0 \otimes 5 \mathrm{~cm}, 5 \nabla 10 \mathrm{~cm}$, and $10 \otimes 20 \mathrm{~cm}$, the C, N and P contents of primary forest are the highest, which is significantly higher than that of shrub grassland, dry land, economic fruit forest and waste grassland. The $\mathrm{C}$ and $\mathrm{N}$ contents in the waste grassland are the lowest, and the $\mathrm{P}$ content in the shrub grassland is the lowest, which is significantly lower than that of the primary forest, sparse forest, and shrub grassland. In addition, the soil C, N, and P contents of 6 different land use types have a trend of decreasing with the increase of soil layers, with obvious surface accumulation characteristics, and the soil C, N, and P contents have significant differences between $0 \sim 5 \mathrm{~cm}$ and $10 \sim 20 \mathrm{~cm}$ soil layers.

\section{Seasonal variation characteristics of soil C, N, P stoichiometric ratios of different land use types}

It can be seen from Fig. 2 that in the six different land use types, the spring soil C:N, C:P, and N:P of different soil layers vary from 10.05 $\sim 14.03,28.15 \sim 46.4,2.52 \sim 4.15$. Among the $0 \sim 20 \mathrm{~cm}$ soil the layers, dry land has the highest $\mathrm{C}: \mathrm{N}$, which is significantly higher than that of primary forest and sparse forest. The C:P and N:P of primary forest and shrub grassland are the highest, which are significantly higher than that of waste grassland. In autumn, the stoichiometric ratios of soil C:N, C:P, and N:P of 6 different land use types vary from $9.28 \sim 14.22,24.23 \sim 46.17,2.14 \sim 4.06$, respectively. In the $0 \sim 20 \mathrm{~cm}$ soil layer, dry land has the highest C: $N$ and C:P, which are significantly higher than that of economic fruit forest and waste grassland. Shrub grassland has the highest N:P, and waste grassland has the lowest N:P, which are significantly lower than the N:P for 5 other land use types. In addition, the soil C:N and N:P of 6 different 
land use types show a decreasing trend with the increase of soil layer. In spring, the soil C:P shows a decreasing trend with the increase of soil layer. In autumn, it shows a trend of first increasing and then decreasing with the increase of soil layer. It shows that seasonal variations have a certain influence on the soil stoichiometry characteristics of different soil layers.

\section{Correlation analysis of soil ecological stoichiometric characteristics and environmental factors of different land use types}

It can be seen from Table 2 that the soil C, N, P of different karst land use types and their stoichiometric ratios have obvious correlations with their environmental factors. In spring, the $\mathrm{C}, \mathrm{N}$, and $\mathrm{P}$ contents of various soil use types are positive correlated with altitude and aspect, and the $\mathrm{C}, \mathrm{N}$ content and $\mathrm{N}: \mathrm{P}$ are extremely significantly positive correlated with landform, and they are negative correlated with slope, rock exposure rate, human activity intensity, and rocky desertification grade. Among them, the human activity intensity is extremely significantly negative correlated with the $\mathrm{C}, \mathrm{N}, \mathrm{P}$ contents and N:P. In autumn, the landform is significantly positive correlated with soil $\mathrm{N}$ and $\mathrm{P}$ content, and negative correlated with C:N. Slope, rock exposure rate, human activity intensity, and rocky desertification grade are mostly still negative correlated with the $\mathrm{C}, \mathrm{N}$, and $\mathrm{P}$ contents of each soil use type. Among them, rock exposure rate and rocky desertification grade are significantly negative correlated with soil $\mathrm{C}$ and $\mathrm{N}$ contents, and human activity intensity is extremely significantly negative correlated with soil $\mathrm{N}$ and $\mathrm{P}$ contents.

Table 2

Correlation analysis of soil ecological stoichiometry characteristics and environmental factors in different land use types

\begin{tabular}{|c|c|c|c|c|c|c|c|c|}
\hline Seasons & Indicators & Altitude & Slope & Aspect & $\begin{array}{l}\text { Rock exposure } \\
\text { rate }\end{array}$ & $\begin{array}{l}\text { Human activity } \\
\text { intensity }\end{array}$ & Landforms & $\begin{array}{l}\text { Rocky } \\
\text { desertification } \\
\text { grades }\end{array}$ \\
\hline \multirow[t]{6}{*}{ spring } & C & 0.184 & $-0.437^{\star}$ & 0.174 & $-0.505^{\star}$ & $-0.616^{\star \star}$ & $0.523^{*}$ & $-0.485^{\star}$ \\
\hline & $N$ & 0.154 & -0.287 & 0.251 & -0.439 & $-0.666^{\star *}$ & $0.609^{\star *}$ & -0.324 \\
\hline & $\mathrm{P}$ & 0.289 & -0.288 & 0.292 & $-0.498^{*}$ & $-0.585^{*}$ & 0.429 & -0.416 \\
\hline & C:N & 0.042 & -0.385 & -0.265 & -0.050 & 0.376 & -0.448 & -0.320 \\
\hline & $\mathrm{C}: \mathrm{P}$ & -0.084 & -0.430 & -0.064 & -0.179 & -0.282 & 0.241 & -0.252 \\
\hline & $N: P$ & -0.095 & -0.191 & 0.109 & -0.157 & $-0.509^{*}$ & $0.512^{*}$ & -0.059 \\
\hline \multirow[t]{6}{*}{ autumn } & C & 0.291 & $-0.519^{*}$ & 0.122 & $-0.620^{\star *}$ & -0.379 & 0.412 & $-0.581^{*}$ \\
\hline & $N$ & 0.224 & -0.266 & 0.114 & -0.376 & $-0.613^{* *}$ & $0.608^{\star \star}$ & -0.348 \\
\hline & $P$ & 0.379 & -0.130 & 0.210 & $-0.510^{*}$ & $-0.611^{\star *}$ & $0.535^{\star}$ & $-0.486^{*}$ \\
\hline & C:N & 0.038 & -0.313 & -0.033 & -0.325 & $0.639^{\star *}$ & $-0.589^{*}$ & -0.314 \\
\hline & C:P & -0.133 & $-0.535^{\star}$ & -0.139 & -0.075 & 0.270 & -0.145 & -0.144 \\
\hline & $\mathrm{N}: \mathrm{P}$ & -0.153 & -0.217 & -0.118 & 0.170 & -0.196 & 0.288 & 0.107 \\
\hline
\end{tabular}

\section{Redundant analysis of soil ecological stoichiometry characteristics and environmental factors of different land use types}

As shown in Table 3, the importance of environmental factors to the soil C, N, P and their stoichiometric ratios in different land use types is ranked as follows: in spring, human activity intensity > landform > slope > rock exposure rate > rocky desertification grade > aspect $>$ altitude, among which influence of human activity intensity and landform on soil C, N, P and their stoichiometric ratios reach a significant level $(\mathrm{P}<0.05)$, and the explanatory variable are $29.1 \%$ and $21.8 \%$, respectively. In autumn, human activity intensity > landform $>$ slope $>$ rock exposure rate $>$ rocky desertification grade $>$ altitude $>$ aspect, among which the influence of human activity 
intensity, landform and slope on soil C, N, P and their stoichiometric ratios reach a significant level $(P<0.05)$, the explanatory variables are $19.9 \%, 18.7 \%$, and $17.5 \%$, respectively.

Table 3

Importance ranking and significance testing in explanatory variable of environmental factors

\begin{tabular}{|c|c|c|c|c|c|}
\hline Season & Environmental factors & Importance ranking & explanatory variable(\%) & Importance(F) & Significance $(P)$ \\
\hline \multirow[t]{7}{*}{ spring } & human activity intensity & 1 & 29.1 & 6.6 & 0.018 \\
\hline & landforms & 2 & 21.8 & 4.5 & 0.028 \\
\hline & slope & 3 & 17.3 & 3.3 & 0.074 \\
\hline & rock exposure rate & 4 & 14.5 & 2.7 & 0.096 \\
\hline & rocky desertification grades & 5 & 13.2 & 2.4 & 0.102 \\
\hline & aspect & 6 & 4.2 & 0.7 & 0.474 \\
\hline & altitude & 7 & 1.7 & 0.3 & 0.736 \\
\hline \multirow[t]{7}{*}{ autumn } & human activity intensity & 1 & 19.9 & 4 & 0.022 \\
\hline & landforms & 2 & 18.7 & 3.7 & 0.038 \\
\hline & slope & 3 & 17.5 & 3.4 & 0.042 \\
\hline & rock exposure rate & 4 & 16.7 & 3.2 & 0.054 \\
\hline & rocky desertification grades & 5 & 15.1 & 2.8 & 0.064 \\
\hline & altitude & 6 & 4.6 & 0.8 & 0.482 \\
\hline & aspect & 7 & 1.5 & 0.2 & 0.86 \\
\hline
\end{tabular}

From the biplots of RDA (Fig. 3), in spring and autumn, the arrow lines of human activity intensity, landform, and slope are the longest, showing that these three environmental factors can play a good role in explaining variation in soil C, N, P and their stoichiometric ratios, the same as the importance ranking results in Table 3. Among them, the angles between the human activity intensity, slope, rock exposure rate, rocky desertification grade and soil C, N, P, etc. are mostly obtuse angles, showing a negative correlation; the angles between landform, aspect, altitude and soil C, N, P are complementary angles, showing a positive correlation; and the arrow between aspect and altitude is the shortest, indicating that it has little influence on the variations of soil C, N, P and their stoichiometric ratios.

\section{Discussion}

\section{The influence of different land use types on soil $\mathrm{C}, \mathrm{N}$, and $\mathrm{P}$ content}

As two important components of the terrestrial ecosystem, soil and plants carry out close material and nutrient cycles and are highly correlated. Soil not only provides nutrients for the growth and development of plants, but also affects the distribution and succession of plant communities, and plants will also improve the soil fertility status of the growing area through the return of root exudates and litter (Zhang et al. 2014; Yao et al. 2018). In this study, the C, N, and P contents of primary forests among the six different land use types are the highest, which are significantly higher than those of shrub grassland, dry land, economic fruit forests, and waste grasslands; the $\mathrm{C}$ and $\mathrm{N}$ contents of wild grasslands are the lowest, which are significantly lower than those of primary forests, sparse forest, shrub grassland; roughly expressed as primary forest > sparse forest > shrub grassland > dry land > economic fruit forest > waste grassland. This is consistent with the research results of Duan Yafeng et al. (2005), Bai Yixin et al. (2020), and Sun Caili et al. (2021). This may be due to the fact that the primary forest is protected by returning farmland to forests, human activities are less disturbed, and the surface is mostly dominated by tall trees. There is abundant litter returning to the soil, which is conducive to the accumulation of soil organic matter. However, the waste grassland is sparsely vegetation, single community and affected by the outside world, so the soil nutrient content is low. In addition, the study also shows that the soil C, N, and P contents of the six different land use types in the study area 
present certain seasonal variations, and the soil $\mathrm{C}, \mathrm{N}$, and $\mathrm{P}$ content in autumn is higher than that in spring. This is also the same as the research result of Zhu Shuying et al. (2005). Generally speaking, the temperature in summer and autumn is higher, the number of microorganisms is high with high activities, and the decomposition rate is fast, which is conducive to the accumulation of soil organic matter; the lower temperature in winter and spring inhibits the activities of soil microorganisms, which is not conducive to accumulate soil organic matter (Sun et al. 2020).

Affected by various factors such as climate, soil microorganisms, plant roots, and litter, the surface soil is prone to accumulation of nutrients, and the phenomenon of "surface accumulation" appears on the vertical section of the soil. In this study, the soil C, N, and P contents of the six different land use types have a trend of decreasing as the soil layer increases. They have obvious surface accumulation characteristics, and the soil C, N, P content between $0 \otimes 5 \mathrm{~cm}$ and $10 \sim 20 \mathrm{~cm}$ soil layer have significant differences. This is also consistent with most research results (Bai et al. 2020). At the same time, compared with other areas, the soil layer in karst areas is shallow, and the phenomenon of soil "surface accumulation" is more obvious. Therefore, protecting the existing primary forests and carrying out reasonable land use methods are of great significance to reduce soil erosion and water loss and increasing soil fertility in rocky desertification areas.

\section{The influence of different land use types on the stoichiometric ratios of soil $\mathrm{C}, \mathrm{N}$, and $\mathrm{P}$}

The variations in the stoichiometric ratio of soil $\mathrm{C}, \mathrm{N}$, and $\mathrm{P}$ reflect the variation in the soil nutrient elements, an indicator to measure the composition and quality of soil nutrients (Fanin et al. 2013). In this study, the variation range of soil C:N in spring and autumn is 10.05 $\sim 14.03$ and $9.28 \sim 14.22$, most of which are lower than the global average soil C:N (13.3), indicating that the organic matter in the study area decompose rapidly and the mineralization effect is obvious, and the soil nitrogen is relatively sufficient, consistent with the study of Bai Yixin et al. (2020). At the same time, dryland soil has the highest C:N among the six land use types, which is significantly higher than that of primary forest and sparse forest. Therefore, protection of primary forests and sparse forest should be strengthened to reduce the loss of nitrogen. The study also shows that the soil C:P in spring and autumn are $28.15 \varangle 46.4,24.23 \varangle 46.17$, and the soil N:P are $2.52 \varangle 4.15,2.14 \varangle 4.06$, which are much higher than the average level of $C: P(19.77)$ and $N: P(1.37)$ of karst soil in the same region, and the C:P and N:P of primary forest and shrub grassland are significantly higher than those of waste grassland. This may be because the karst area is rich in rainfall and strong leaching. Compared with other ecosystems, the $\mathrm{P}$ content is lower, reflecting a certain degree of $\mathrm{P}$ element limitation, which is the same as the study of Bao Gan et al. (2017).

\section{The influence of environmental factors on the soil ecological stoichiometric characteristics in different land use types}

Soil is an important part of the terrestrial ecosystem, and its nutrient characteristics are jointly affected by many environmental factors such as vegetation type, climate, and land use type (Wang et al. 2018). The 7 environmental factors in this study (human activity intensity, landform, slope, rock exposure rate, rocky desertification grade, slope aspect, altitude) are all related to the stoichiometric characteristics of soil C, N, P of different land use types. Among them, human activity intensity, landform, and slope are the main environmental factors that significantly affect the variations in the stoichiometric characteristics of soil nutrients in spring and autumn. Approximately, the soil C, N, and P contents are significantly negative correlated with human activity intensity, slope, while it is mostly positive correlated with the landform. Related studies have shown that strong human activities are one of the important driving forces for rocky desertification. Human activities such as farming, grazing, and cutting fuelwood have changed the nutrient cycle process of the karst ecosystem, which will cause a series of ecological problems such as soil erosion and aggravation of rocky desertification to varying degrees (Wu et al. 2020), the same as the research results of Wang Weiqi et al. (2010). At the same time, due to the rugged and uneven surface, large undulations, abundant and concentrated precipitation in karst mountainous areas, slope is an important driving factor for soil nutrient loss. In this study, slope is negatively correlated with soil stoichiometric characteristics, probably related to the nutrient distribution of different terrain parts. Compared with eroded steep slopes, the soil layers of the valley terrain have higher nutrient content and more obvious loss, which is the same as the study of Hu et al. (2020). In addition, the karst area in southwest China has a large area and extensive development of karst landforms, resulting in high spatial heterogeneity and discontinuous soil distribution in this area. The landforms have also become an important environmental factor that affects the variations in soil nutrient characteristics (Zhang et al. 2011; Zheng et al. 2020). The study also found that except the above three main environmental factors, rock exposure rate, rocky desertification grade, altitude, and aspect also have varying degrees of influence on the soil stoichiometric characteristics in

Page $8 / 13$ 
different land use types. It should be pointed out that climatic factors are also important factors affecting karst soil nutrient variations. In view of the fact that temperature, precipitation, humidity and other climatic factors are not involved in this experiment, relevant research will be carried out in the later period to improve the impact mechanism of environmental factors in karst areas on soil ecological stoichiometry of different land use types.

\section{Conclusion}

(1) Among the six different land use types, the $\mathrm{C}, \mathrm{N}$, and $\mathrm{P}$ contents of the primary forest are the highest, which are significantly higher than that of shrub grassland, dry land, economic fruit forest, and waste grassland. The $\mathrm{C}$ and $\mathrm{N}$ contents of the waste grassland are the lowest, which are significantly lower than that of the primary forest, sparse forest and shrub grassland, roughly expressed as primary forest > sparse forest > shrub grassland > dry land > economic fruit forest > waste grassland. The soil C, N, and P present certain seasonal variations, which are represented by the soil $\mathrm{C}, \mathrm{N}$ and $\mathrm{P}$ in autumn is higher than that in spring. In addition, the soil $\mathrm{C}, \mathrm{N}$, and $\mathrm{P}$ contents of the six different land use types have an overall trend of decreasing with the increase of soil layers, which has obvious characteristics of surface accumulation.

(2) In the six different land use types, the $\mathrm{C}: \mathrm{N}$ of spring and autumn soils are lower than the national and global averages, while $\mathrm{C}: \mathrm{P}$ and $\mathrm{N}: \mathrm{P}$ are much higher than the averages of karst soils in the same area, indicating that the soil in the study area is relatively sufficient in $\mathrm{N}$ and $\mathrm{P}$ is relatively lacking.

(3) The main environmental factors that affect the variations in the stoichiometric characteristics of soil $\mathrm{C}, \mathrm{N}$, and $\mathrm{P}$ in different land use types are the human activity intensity, landform, and slope.

\section{Declarations}

Acknowledgements This work are supports by the World Top Discipline Program of Guizhou Province (No. 1252019 Qianjiao Keyan Fa); the Key Project of Science and Technology Program of Guizhou Province (No. 54112017 Qiankehe Pingtai Rencai).

Conflict of interest The authors declare that they have no conflicts of interest.

\section{References}

1. Bai YX, Sheng MY, Xiao HL, Hu QJ 2020 Effects of Typical Rocky Desertification Control Measures on Soil Organic Carbon, Nitrogen, and Components. Journal of Soil and Water Conservation 34: 170-177.

2. Bao Q, Yang R, Nie CJ, Li WH, LIU YZ. 2017 Soil nutrient characteristics of different restoration patterns in Huajiang gorge of Guizhou karst plateau. Chinese Journal of Ecology 36: 2094-2102.

3. Cai YL 1999 Ecological rehabilitation and development of agriculture, forestry and animal husbandry in Karst mountain areas of southwest China: Status and trend of study. Resources Science 21: 37-41.

4. Chi YK, Xiong KN., Xiao H, Chen H (2020) Study on the relationship between disposition models of forest and grass and soil properties in karst rocky desertification areas of southwest China. Fresenius Environmental Bulletin 29: 5424-5431.

5. Duan YF, Wang KL, Feng D, Wu M, Zhang W, Chen HS 2018 Response of the spatial pattern of soil organic carbon and total nitrogen to vegetation restoration in a typical small karst catchment. Acta Ecologica Sinica 38: 1560-1568.

6. Fanin N, Fromin N, Buatois B, Ttenschwiler S, Cleland E 2013 An experimental test of the hypothesis of non-homeostatic consumer stoichiometry in a plant litter-microbe system. Ecology Letters 16: 764-772.

7. Gao XL, Li XG, Zhao L, Kuzyakov Y 2019 Regulation of soil phosphorus cycling in grasslands by shrubs[J]. Soil Biology and Biochemistry 133: 1-11.

8. Hu QJ, Sheng MY, Bai YX, Yin J, Xiao HL 2020 Response of C, N, and P stoichiometry characteristics of Broussonetia papyrifera to altitude gradients and soil nutrients in the karst rocky ecosystem, SW China. Plant and Soil 23: 453-457.

9. Jiang ZC, Lian YQ, Qin XQ (2014) Rocky desertification in Southwest China: Impacts, causes, and restoration. Earth-Science Reviews 132: 1-12.

10. Liu F, Wang SJ, Liu YS, He TB, Luo HB, Long J 2005 Changes of soil quality in the process of karst rocky desertification and evaluation of impact on ecological environment. Acta Ecologica Sinica 25: 639-644.

11. Lu RK. 1999 Soil chemical analysis. China Agricultural Science and Technology Press, Beijing, p 21-32. 
12. Sheng MY, Xiong KN, Cui GY, Liu Y (2015) Plant diversity and soil physical-chemical properties in karst rocky desertification ecosystem of Guizhou, China. Acta Ecologica Sinica 35: 434-448.

13. Sun CL, Wang YW, Wang CJ, Li QJ, Wu ZH, Yuan DS, Zhang JL 2021 Effects of land use conversion on soil extracellular enzyme activity and its stoichiometric characteristics in karst mountainous area. Acta Ecologica Sinica 41: 1-10.

14. Sun FD, LI F, Chen WY, Zhu C, Zhou S, Gou WL, Liu L, Zhou JQ 2020 Seasonal dynamics of soil physicochemical properties, enzyme activity and microbial community of rodents-damaged alpine wetlands by plateau zoker (Myospalax baileyi) in Zogie, southwest China. Acta Ecologica Sinica 40: 2396-2406.

15. Wang KL, Yue YM, Chen HS, Wu XB, Xiao J, Qi XK, Zhang W, Du H (2019) The comprehensive treatment of karst rocky desertification and its regional restoration effects. Acta Ecologica Sinica 39: 7432-7440.

16. Wang LJ, Wang P, Sheng MY. 2018 Stoichiometric characteristics of soil nutrient elements and its influencing factors in typical karst rocky desertification ecosystems, Southwest China. Acta Ecologica Sinica 38: 6580-6593.

17. Wang P, Wang LJ, Sheng MY 2018 Plant diversity,ecological stoichiometry characteristics of soils and their correlation of the karst rocky desertification ecosystem in southwestern China. Journal of Southern Agriculture 49: 1959-1969.

18. Wang SJ, Zhang DF, Li RL (2002) Mechanism of rocky desertification in the karst mountain areas of Guizhou province, southwest China. International Review for Environmental Strategies 3: 123-135.

19. Wang WQ, Zeng CS, Zhong CQ, Tong C 2010 Effect of Human Disturbance on Ecological Stoichiometry Characteristics of Soil Carbon, Nitrogen and Phosphorus in Minjiang River Estuarine Wetland. Chinese Journal of Environmental Science 31: 2411-2416.

20. Wardle DA, Walker LR, Bardgett RD 2004 Ecosystem Properties and Forest Decline in Contrasting Long-Term Chronosequences. Science 305: 509-513.

21. Wu LF, Wang ZQ, Wang Y, Liu YG, Yang B, Zhang YF 2019 Relationship between Soil C, N, P Stoichiometric Characteristics and Enzyme Activity in Karst Plateau Soils with Different Degree of Rocky Desertification. Ecology and Environment Sciences 28: 23322340 .

22. Wu ZY, Zhang C, Jiang ZC, Luo WQ, Xiao Q, Hu ZX, Wu HY 2020 Subsoil carbonate dissolution rates and their determining factors in a karst drainage basin, SW China. Environmental Earth Sciences 79: 508.

23. Xiong KN, Chi YK (2015) The problems in Southern China karst ecosystem in southern of china and its countermeasure. Ecological Economy 31: 23-30.

24. Xiong KN, Li J, Long MZ 2012 Features of Soil and Water Loss and Key Issues in Demonstration Areas for Combating Karst Rocky Desertification. Acta Geographica Sinica 67: 878-888.

25. Yao XD, Zhang NL, Zeng H. 2018 Effects of soil depth and plant-soil interaction onmicrobial community in temperate grasslands of northern China. Science of the total environment 630: 96-102.

26. Zeng FM, Jiang ZC, Shen LN, Chen W, Yang QY, Zhang C (2018) Assessment of multiple and interacting modes of soil loss in the karst critical zone, Southwest China (SWC). Geomorphology 322: 97-106

27. Zeng ZX, Wang KL, Liu XL, Zeng FP, Song TQ, Peng WX, Zhang H, Du H 2015 Stoichiometric characteristics of plants, litter and soils in karst plant communities of North-west Guangxi. Chinese Journal of Plant Ecology 39: 682-693.

28. Zhang WM, Wu M, Wang M, Shao XX, Jiang XS, Zhou B 2014 Distribution characteristics of organic carbon and its components in soils under different types of vegetation in wetland of Hangzhou Bay. Acta Pedologica Sinica 51: 1351-1360.

29. Zhang YH, Xu XL, Li ZW, Liu MX, Xu CH, Zhang RF, Luo W (2018) Effects of vegetation restoration on soil quality in degraded karst landscapes of southwest China. The science of the total environment 650: 2657-2665.

30. Zhang ZH, Hu G, Zhu J, Ni J 2011 Spatial heterogeneity of soil nutrients and its impact on tree species distribution in a karst forest of Southwest China. Chinese Journal of Plant Ecology 35: 1038-1049.

31. Zhao C, Sheng MY, Bai YX, Liu SX 2021 Soil available nitrogen and phosphorus contents and the environmental impact factors across different land use types in typical karst rocky desertification area, Southwest China Chinese Journal of Applied Ecology 32 : 1383-1392.

32. Zheng L, Long CL. 2020 Eco-stoichiometric characteristics of soil in different topographical sites of Maolan karst forest. Journal of Southern Agriculture 51: 545-551.

33. Zhu SY, Yan LB, Pi FJ, Yu LF, Yuan CJ, Shu LX 2019 Stoichiometric characteristics and seasonal variation of soils and dominant plant leaves in secondary forest in karst area. Journal of Southern Agriculture 50: 90-96. 


\section{Figures}
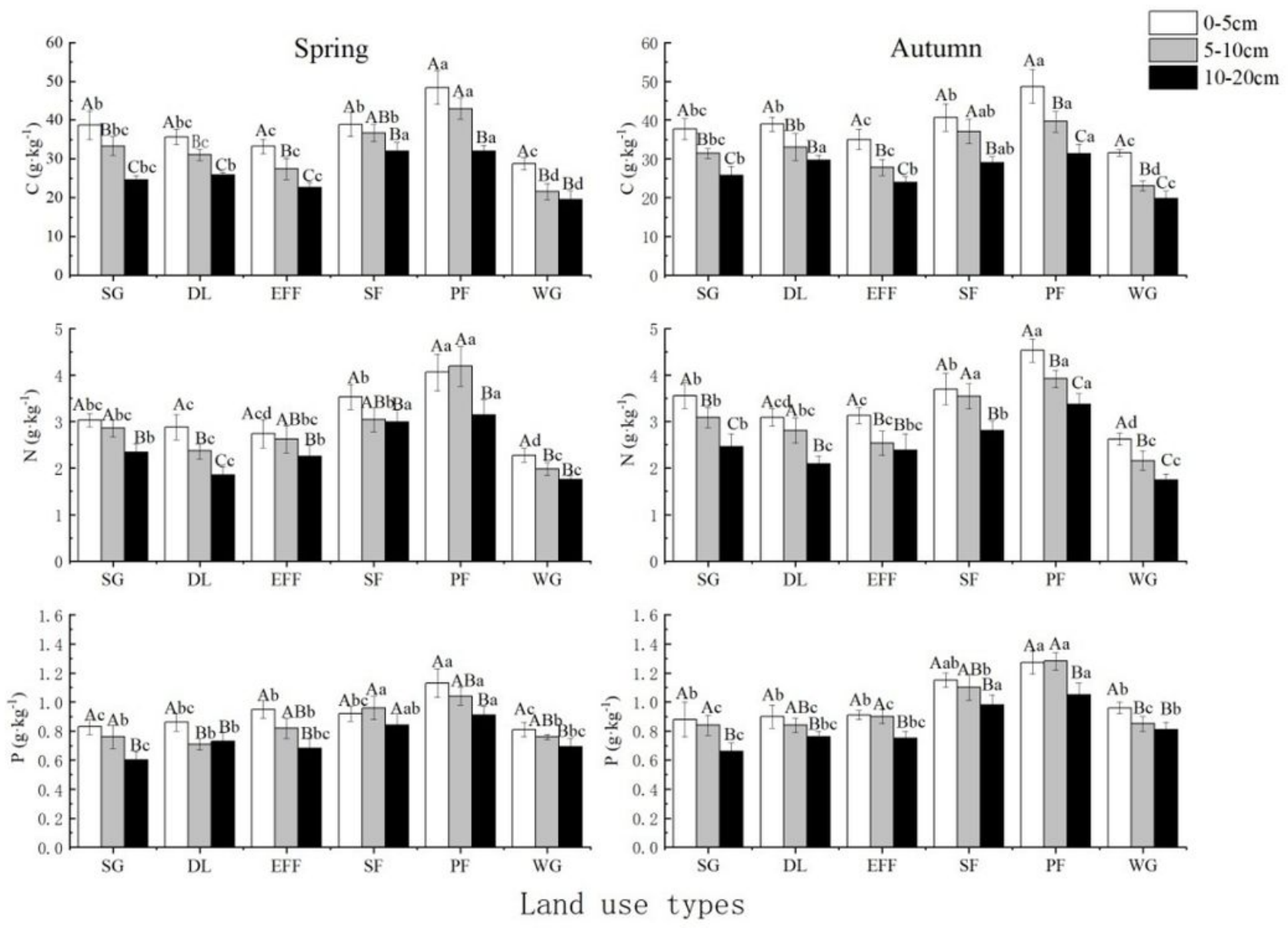

Figure 1

Seasonal variation characteristics of soil C, N, P contents in different land use types 

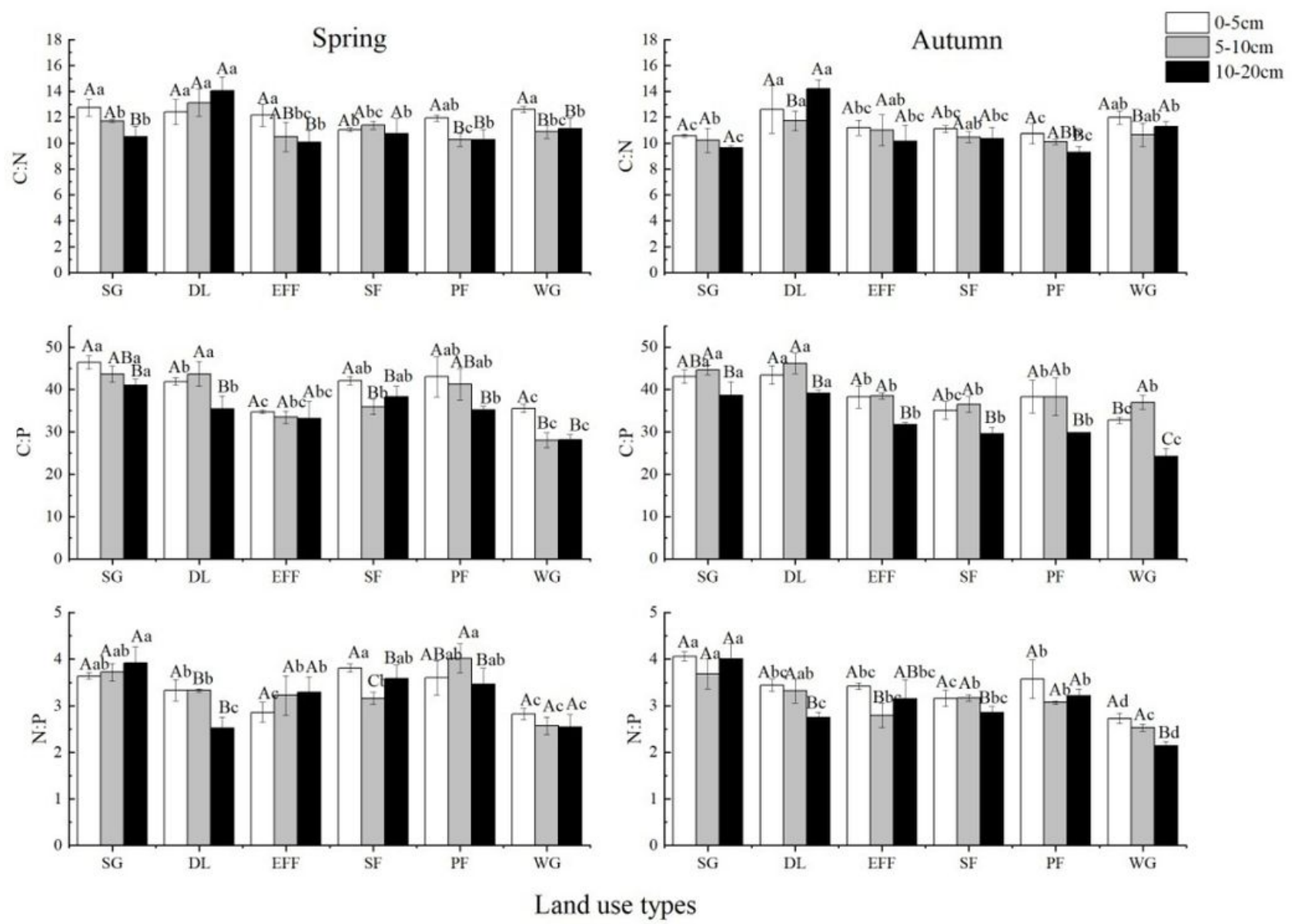

Figure 2

Seasonal variation characteristics of soil C, N, P stoichiometric ratios in different land use types 

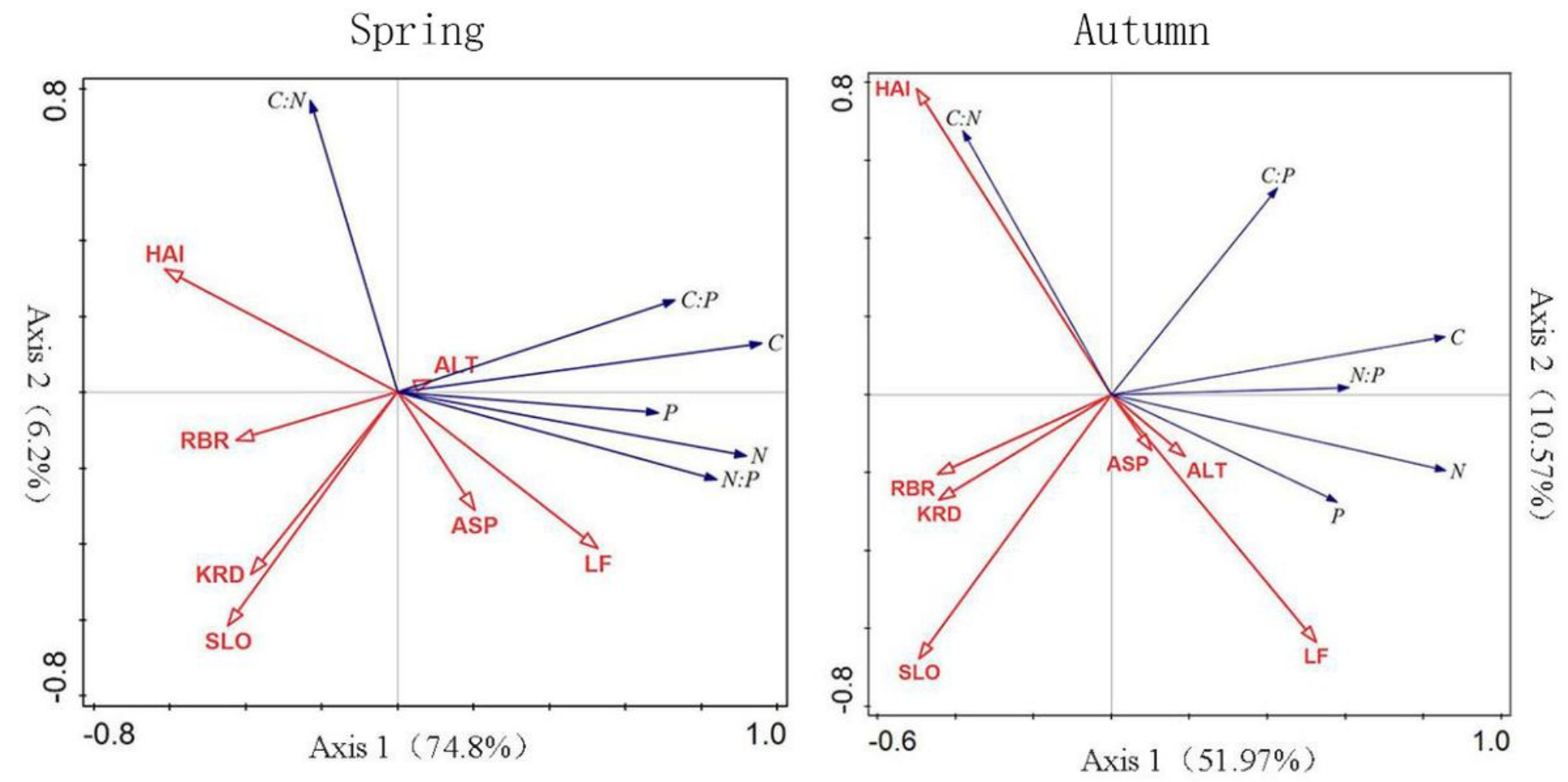

Figure 3

Biplots of RDA for environmental factors with soil stoichiometric characteristics in different land use types 